\title{
EKSISTENSI HOME INDUSTRY BERBASIS GENDER DI KOTA MALANG
}

\section{Anggaunitakiranantika ${ }^{1 *}$}

Diterima 18 Februari 2019, Dipublikasikan 30 April 2019

(CPenulis (2019)

\begin{abstract}
There are many industry sector in Malang City, one of them is Cornflakes Industry which located on Kelurahan Pandanwangi, Kecamatan Blimbing, Malang City. This industry, is running for over 25 years and must facing business competition in industrialized era. For their sustainability, this industry is supported by social capital strengthness. In order to preserving home industries which producing cornflake, there are some components in society who directly supports such as: business owner, employee, and laborer. Research was conducted by qualitative research with gender approach. This research aims for analyzing social capital role on cornflake home industry in Malang City, elaborating social phenomena in industrial sector with economy sociological context and identifying how social capital works on cornflake industrial relationship in Malang City. Research was found that social capital among industrial relation are created social bonding among societies which created by kinship and neighborhood system, then, strengthening cooperation between employee, employer, labor, supplier, consumen and Malang City government for supporting each other due to local commodity from home industry sector. Finally, research finding if social capital will determined industrial existences in the future based on product necessity like cornflake as local commodity has declared by Tourism Indonesia Government as premium local food product from Malang City.
\end{abstract}

Keywords

Social network, home industry, Malang

\section{PENDAHULUAN}

Seiring dengan modernisasi yang mengikuti kehidupan masyarakat di Kota Malang, pertumbuhan industri-industri di bidang usaha kecil dan menengah dalam berbagai bidang juga tak terhindarkan untuk terus berjalan. Keberadaan sebuah industri kecil berhubungan erat dengan sumber daya manusia. Sebuah industri kecil yang didirikan mempunyai tujuan yang hendak dicapai seperti membuka peluang kerja baru dan tingkat partisipasi masyarakat dalam mengakses kehidupan yang layak sehingga dapat memenuhi kesejahteraan hidup, baik bagi laki-laki ataupun perempuan, baik tua ataupun muda tanpa membedakan latar belakang sosial, politik, ekonomi dan budayanya.

Di Kota Malang, sebagai kota yang memiliki ciri khas dalam industri kreatif, masyarakat dapat menemukan berbagai produk local dengan mudah, yang pada umumnya merupakan hasil usaha atau industri kecil pada industri informal maupun tradisional. Salah satunya adalah industri makanan tradisional yakni makanan emping jagung. Di Kelurahan

\footnotetext{
${ }^{1}$ Jurusan Sosiologi FIS UM

anggaunita.fis@um.ac.id
} 
Pandawangi, Kecamatan Blimbing, Kota Malang terdapat perkampungan yang dinamakan Kampung Terongdowo yang berada di Jalan Teluk Bayur. Di lokasi ini terdapat banyak produsen emping atau marning jagung. Ada sekitar 19 industri rumahan milik warga yang sudah puluhan tahun menekuni usaha tersebut. Berdasarkan studi pendahuluan yang dilakukan, pelaku industri rumahan emping jagung selalu berusaha untuk memenuhi permintaan pasar. Para pengelola usaha ini membuat beberapa macam olahan, baik rasa, kemasan, dan jenis emping jagung yang diproduksi. Pertama adalah marning biasa dengan ciri khas rasanya gurih dan renyah, kedua marning gepeng (pipih) dengan rasa gurih, rasa manis pedas, balado, keju, udang, barbeque, ayam bawang dan banyak varian rasa lainnya. Diharapkan, dengan menghadirkan banyak varian baik rasa, jenis dan kemasan maka konsumen dapat memilih sesuai selera yang diinginkan. Harga yang ditawarkan untuk hasil olahan emping jagung ini cukup terjangkau, biasanya untuk marning biasa perkilo dijual Rp. 10.000 - 20.000 sedangkan marning jagung yang beraneka rasa dijual dengan harga Rp. 15.000-25.000 perkilo. Pangsa pasar marning jagung produksi Pandawangi, selain memenuhi permintaan masyarakat lokal di Kota Malang juga telah banyak permintaan dari luar kota. Dengan kemampuan produksi 1-3 kwintal perhari dari tiap home industry, biasanya setiap pengiriman emping jagung ke konsumen mencapai 3T perminggu. Permintaan ini sapat mengalami kenaikan pada musim tertentu, seperti saat liburan sekolah atau menjelang hari raya dan hari besar.

Besarnya permintaan pasar terhadap produk local emping jagung sangat menentukan kelangsungan usaha industri rumahan nantinya karena di dalam industri emping jagung tersebut terbentuk suatu hubungan-hubungan sosial. Dalam hubungan sosial yang dilakukan pemilik industri emping jagung diantaranya dengan tenaga kerjanya, pemilik usaha dengan tengkulaknya, karyawannya dengan pelanggannya, dan pengusaha dengan pemasok bahan baku atau suppliernya. Selain itu pula terdapat peran dalam jaringan sosial yang tidak bisa dikesampingkan karena memiliki aturan-aturan tertentu untuk mengikat pihak yang berkepentingan selama bekerja sama. Dalam perkembangannya, industri rumahan memiliki aspek multidimensional dalam masyarakat, tidak sekedar peningkatan sektor ekonomi melalui pekerjaan dan pendapatan saja. Tetapi juga mengenai ketrampilan dalam melakukan pengolahan dan manajemen emping jagung dari lingkungan di Kampung Terongdowo mengingat industri rumahan ini mulai menjadi komoditas export unggulan dari Kota Malang sejak tahu 2016 lalu.

Tidak terlepas dari industri rumahan emping jagung saat ini, peran perempuan menjadi menarik untuk diperhatikan karena perempuan tidak lagi menggantungkan hidupnya secara penuh kepada suaminya dalam pemenuhan kebutuhan ekonomi keluarga tetapi ia juga turut memikirkan pendapatan pribadinya sebagai bentuk kepedulian atas kelangsungan hidup keluarganya. Saat ini banyak perempuan yang bekerja menjadi roda penggerak perekonomian (Purnomo, 2015) dalam masyarakat dewasa ini . Di Kota Malang, perempuan yang bekerja memiliki jumlah yang signifikan baik dalam ragam sektor pekerjaannya maupun dalam jumlahnya dari tahun ke tahun, hal ini ditunjang dengan data yang didapatkan pada 2018 yang menunjukkan bahwa tingkat partisipasi kerja perempuan sebesar 51,76\% (dengan jumlah 30.939) sebelumnya pada tahun 2017 sebesar 48,34\% (dengan jumlah 25.927 ) (Kota Malang dalam Angka, 2018). Kondisi ini masih sangat jauh 
dibandingkan dengan partisipasi angkatan kerja laki-laki yang mencapai $78.38 \%$ di tahun 2018 .

Berkembangnya jaringan sosial dalam industri emping jagung dan peran serta laki-laki perempuan sebagai pengelola industri rumahan di Kota Malang ini mendorong peneliti mengkaji lebih jauh tentang keterkaitan hubungan jaringan sosial dan keberlangsungan usaha, di tengah dinamika usaha dan relevansi pada kondisi masyarakat Kota Malang. Keterkaitan ini bertumpu pada perilaku sosial yang ada pada diri pelaku usaha rumahan emping jagung, yang membuat ketertarikan pada penulis untuk meneliti lebih jauh.

\section{KERANGKA KONSEPTUAL}

Jaringan sosial dalam aspek bisnis juga dapat dijumpai dalam masyarakat Cina Asia Tenggara, Seperti dalam lingkungan bisnisnya. Secara empiris, jaringan sosial mereka dalam bisnis dibangun atas dasar hubungan sosial yang sudah terbentuk di antara para anggota jaringan. Adanya pola jaringan (xinyong dan guanxi) dapat terbentuk dalam pola konstruksi budaya yang telah mengakar pada mereka, karena adanya hubungan pribadi dan kesepakatan yang didukung oleh sanksi-sanksi kelompok informal yang dikaitkan dengan reputasi seseorang dalam jaringan tempatnya bergabung, penanaman kepercayaan, tingginya solidaritas sosial dan sebuah masyarakat yang relatif tanpa kelas dan bebas dapat menciptakan nilai-nilai kebaikan yang kondusif bagi penanganan bisnis yang berhasil di kalangan mereka (Hefner, 2018: 107).

Jaringan sosial merupakan hubungan-hubungan yang tercipta antar banyak individu dalam suatu kelompok ataupun antar suatu kelompok dengan kelompok lainnya. Hubungan-hubungan yang terjadi bisa dalam bentuk yang formal maupun bentuk informal. Hubungan sosial adalah gambaran atau cerminan dari kerjasama dan koordinasi antar warga yang didasari oleh ikatan sosial yang aktif dan bersifat resiprosikal (Damsar, 2002:157). Sementara itu, jaringan sosial dianalogikan sebagai hubungan-hubungan yang tercipta antara banyak individu dalam suatu kelompok atau kelompok ataupun suatu kelompok dan kelompok lainnya. Analisis jaringan sosial lebih ingin mempelajari keteraturan individu atau kelompok berperilaku ketimbang keteraturan keyakinan tentang keyakinan tentang bagaimana mereka khususnya berperilaku (Ritzer, George. 2004: 382),

Jaringan sosial dapat digunakan untuk menginterprestasikan tingkah laku individu dalam berbagai kondisi sosial masyarakat yang melatarbelakanginya. Terdapat dua karakteristik penting dari jaringan sosial yaitu, (1) morfologi yang terdiri dari 4 unsur, totalitas hubungan, perilaku individu, hubungan antarindividu, dan kontak antarindividu dalam jaringan serta (2) interaksional yang terdiri dari 5 unsur, tujuan hubungan, orientasi hubungan, jangka waktu, kebebasan dalam jaringan sosial, dan kontak individu dalam jaringan (Mitchell J. Cylde. 1969; Wijaya, Mahendra. 2007)

Aktivitas sekelompok individu yang menjadi suatu tindakan sosial maka teori jaringan sosial berperan dalam sistem sosial. Dengan menitik beratkan pada persoalan agregasi, yaitu bagaimana aktivitas sekelompok individu dapat menimbulkan efek sosial yang dapat diamati secara empiris. Teori jaringan sosial berangkat dari pengkajian atas variasi bagaimana perilaku individu berkumpul menjadi perilaku kolektif yang dilakukan oleh individu dalam kesehariannya. Konsep jaringan sosial menurut peneliti lebih relevan dipakai karena unsur-unsur yang dijelaskan dalam definisi konsep jaringan sosial ini lebih 
sesuai dengan latar belakang dan keberanekaragaman kehidupan sosial dari kehidupan pemilik-karyawan pada industri rumahan emping jagung di Kota Malang. Lebih lanjut, analisis jaringan sosial masih belum menyentuh ranah gender sehingga akan lebih komperehensif apabila fenomena tersebut dapat dijelaskan serta dianalisis secara lebih fokus menggunakan substansi gender dalam melengkapi konsep dan unsur jaringan sosial dalam masyarakat sebagai sebuah fenomena kolektivitas sosial yang melekat dalam kehidupan masyarakat sampai saat ini.

\section{METODE}

Penelitian ini dilakukan dengan metode kualitatif. Pengumpulan data dilakukan dengan cara observasi, wawancara, dan dokumentasi. Analisis data penelitian dilakukan dengan memperhatikan reduksi data, display data sampai pada penarikan kesimpulan sebagai hasil penelitian. Lokasinya di Kelurahan Pandanwangi, Kecamatan Blimbing, Kota Malang. Alasan dipilihnya Kelurahan Pandanwangi sebagai lokasi penelitian adalah; (1) Terdapat industri emping jagung yang tetap eksis di Kota Malang, bahkan mengalami perkembangan yang pesat sebagai pemasok jajanan tradisional di tengah berkembangnya jaman saat ini, (2) Hasil dari industri emping jagung di Kelurahan Pandanwangi selain untuk memenuhi kebutuhan mata pencaharian masyarakat di sekitar, juga merupakan komoditas unggulan untuk memenuhi kebutuhan konsumsi masyarakat lokal, regional hingga internasional, dan (3) Adanya kemudahan untuk mendapatkan data, informasi dan referensi yang dibutuhkan.

Metode penelitian ini bertujuan untuk mengetahui keadaan yang jelas, dapat digunakan untuk kepentingan peneliti untuk mengelaborasi teori dengan temuan penelitian serta mengembangkan kajian sosiologi industri yang berperspektif gender secara khusus dan berguna untuk referensi masyarakat pada umumnya.

Pendekatan penelitian yang digunakan adalah deskriptif kualitatif yang berarti interpretasi terhadap isi dibuat dan disusun secara sistematik/menyeluruh dan sistematis. Data yang diperoleh (berupa kata-kata, gambar, perilaku) tidak dituangkan dalam bilangan atau angka statistik, melainkan tetap dalam bentuk narasi yang dimaksudkan untuk mendapatkan kekayaan data yang sangat beragam dari fenomena sosial yang diteliti. Melalui penelitian yang bersifat kualitatif, peneliti mendapatkan data deskriptif tersebut. Cara ini dilaksanakan dengan maksud agar peneliti dapat mendapatkan mutu penelitian dan kedalaman uraian serta ingin membahas materi yang disesuaikan dengan landasan teori yang sudah dipilih sesuai dengan fenomena sosial yang ada dalam masyarakat.

\section{HASIL DAN PEMBAHASAN Jaringan Sosial Home Industry dalam Sumberdaya Ekonomi}

Jaringan sosial adalah hubungan-hubungan sosial relatif berlangsung lama dan terpola. Hubungan-hubungan sosial yang terjadi sekali saja di antara dua orang individu bukan merupakan jaringan sosial. Jaringan sosial penting dalam transaksi atau pertukaran ekonomi. Arti penting jaringan sosial dalam transaksi ekonomi ditunjukkan oleh Granovetter (1985, 2005), Biggart (2001), Macaluay (1963), Podolny (1998). Jaringan sosial yang padat yang melibatkan banyak orang (anggota) dalam suatu komunitas bisa mencegah terjadinya pelanggaran norma, mempermudah penyebaran informasi dan 
meningkatkan solidaritas sosial (Field, 2010: 88). Masyarakat yang komunitasnya memiliki banyak jaringan sosial padat lebih konduksif bagi pembangunan ekonomi (Field, 2010:91). Arti penting jaringan sosial dalam konsep sosiologi ekonomi menjadi lebih diperhatikan oleh sosiolog setelah tulisan Granovetter diterbitkan.

Berdasarkan hasil observasi yang dilakukan, modal ekonomi para pemilik dan pengelola usaha home industry emping jagung di Kota Malang hamper secara keseluruhan memiliki hubungan-hubungan keluarga seperti orang tua-anak, kakak-adik, paman-kemenakan, dan sebagainya. Dasar dari hubungan-hubungan keluarga sebagai modal sosial di samping motif altruistik adalah kepercayaan. Beberapa pemilik usaha yang cukup sukses pada saat ini merupakan pemilik usaha rumahan yang memiliki hubungan keluarga satu dengan yang lain. Adanya ikatan kekerabatan berupa hubungan keluarga bdalam menjalankan sebuah usaha diyakini mampu memberikan sumber modal ekonomi baik uang maupun modal ekonomi yang lain. Modal ekonomi yang bisa diperoleh melalui hubungan-hubungan keluarga berupa pinjaman modal, warisan, pemberian bagian pekerjaan sub-kontrak dan penggunaan fasilitas bersama. Pinjaman berupa modal uang biasanya hanya dalam jumlah yang kecil. Untuk pinjaman dalam jumlah yang besar biasanya pemilik usaha akan memiliki kredit usaha pada bank. Dalam hal pinjaman, juga ditemukan pada industri rumahan melalui hubungan relasional. Pinjaman ini biasanya dilakukan oleh seorang pengusaha pada pengusaha lain yang hubungannya sangat dekat misalya kakak-adik atau orang tua-anak. Warisan yang diberikan kepada pengusaha emping jagung merupakan salah satu cara dalam mendapatkan modal usaha. Sebagaian pengusaha yang masih muda biasanya mendapatkan warisan dari orang tuanya berupa unit usaha. Orang tua tersebut sudah lanjut usia kemudian mengurangi kegiatan usahanya dan memberikan sebagian usaha dan modalnya kepada anak-anaknya. Pemberian warisan usaha biasanya didahului oleh proses pelatihan dimana anak-anak membantu mengerjakan pekerjaan-pekerjaan dalam usaha orang tuanya.

Sejalan dengan hal tersebut, peran yang dimiliki oleh laki-perempuan dalam modal ekonomi dalam industri rumahan emping jagung di Kota Malang merupakan hal yang penting untuk dicermati dalam eksistensi industri rumahan emping jagung di Kota Malang. Berdasarkan hasil wawancara, keterlibatan perempuan dalam industri rumahan ini merupakan salah satu cara yang dilakukan oleh perempuan untuk memiliki penghasilan sendiri dan meningkatkan ekonomi keluarga. Dengan terlibat dalam kegiatan di ranah publik menunjukkan adanya keberdayaan dan kemandirian para perempuan sebagai pemilik usaha rumahan emping jagung tidak dikesampingkan. Peran perempuan dalam usaha, ternyata bermanfaat sebagai ujung tombak keberlangsungan usaha ini, karena dalam kesehariannya yang menghitung seluruh transaksi keuangan dan aliran uang (cashflow) dalam usaha ini adalah perempuan. Lebih lanjut lagi, peran perempuan tidak berhenti disitu saja. Perempuan yang berperan sebagai pemilik usaha ataupun karyawan yang mengurus kredit atau pinjaman dari bank terkait dengan jumlah pasokan bahan baku dan pasaran untuk keberlangsungan usaha ini. Sementara perempuan yang menjadi buruh dalam industri ini berperan untuk memilah dan memilih konsumen dan tengkulak yang datang dan memberikan harga tawar yang bersaing. Banyaknya perempuan yang memilih untuk ikut berperan dalam usaha ini (terutama mereka yang tinggal di sekitar Kampung Terongdowo, tempat industri rumahan) secara otomatis akan membuat perempuan semakin 
banyak berkiprah dalam kegiatan perekonomian, sehingga perempuan menjadi dominan dalam mengontrol keuangan keluarga, dan mampu bertabggungjawab secara lebih atas eksistensi usaha yang dikelola. Kemandirian perempuan terbukti dari kemampuannya dalam melakukan peran ganda, yaitu bekerja di dalam rumah tangga dan di luar rumah tangga sebagai pemilik usaha emping jagung. Seperti halnya di Kota Malang, banyaknya perempuan yang mengelola industri rumahan emping jagung dilatar belakangi oleh adanya keharusan untuk bekerja, bukan suatu pilihan.

Secara ekonomi, peran laki-laki dalam industri rumahan pengolahan emping jagung ini Nampak pada penentuan hubungan industrial, seperti hubungan sub-kontrak yang dibuat oleh para pemilik usaha emping jagung. Pemberian bagian pekerjaan sub-kontrak terjadi dalam bentuk pengusaha emping jagung memberikan pekerjaan sub-kontrak pada orang yang masih memiliki hubungan keluarga dan penerima pekerjaan sub-kontrak memberikan lagi bagian pekerjaannya kepada orang lain yang masih memiliki hubungan keluarga. Pertimbangan yang dijadikan dasar pemberian pekerjaan sub-kontrak ini adalah membantu keluarga. Namun demikian, ketrampilan dalam mengerjakan pekerjaan juga menjadi pertimbangan dalam memberikan sub-kontrak. Dalam industri rumahan ini, karyawan lakilaki lebih memiliki peran untuk mengecek ketersediaan hasil produksi olahan emping jagung dan dilaporkan pada karyawan perempuan. Sementara buruh laki-laki dalam usaha ini lebih berperan sebagai tenaga untuk mengemas hasil produksi olahan emping jagung sebelum disalurkan ke konsumen dan tengkulak.

Sejalan dengan pemikiran Granovetter, hubungan sosial yang terjadi sekali saja di antara dua orang individu dapat dikatakan bukan merupakan jaringan sosial. Hubungan sosial atau jaringan yang terbentuk pada industri rumahan emping jagung ini rata-rata telah terjalin sejak lama karena hubungan kekerabatan atau tercipta karena lingkungan bertetangga secara turun temurun, sehingga ikatan sosial yang tercipta masyarakat sudah terpola. Jaringan sosial yang padat yang melibatkan banyak orang (anggota) dalam suatu komunitas bisa mencegah terjadinya pelanggaran norma, mempermudah penyebaran informasi dan meningkatkan solidaritas sosial (Field, 2010: 88). Berdasarkan hasil observasi yang dilakukan pada industri rumahan emping jagung di Kota Malang, jaringan sosial yang tercipta dalam industri ini sangat padat karena melibatkan anggota masyarakat yang sangat banyak, tanpa membedakan jenais kelaminnya ataupun usianya. Hubungan kekerabatan dalam keluarga besar dan lingkungan bertetangga yang menyokong eksistensi industri rumahan ini turut menginternalisasikan berbagai norma yang dilakukan secara turun temurun, menciptakan dan meningkatkan solidaritas sosial dalam masyarakat karena adanya ikatan sosial yang berlangsung sejak lama dan turut menyebarluaskan informasi pada masyarakat luas, baik lokal maupun nasional mengenai berbagai hal yang menyangkut produk olahan emping yang berasal dari Kota Malang. Bahkan, Pemerintah Kota Malang turut meendukung dan mensupport industri rumahan emping jagung untuk memperluas ekspansinya dan menjadikan komoditas export unggulan khas jajanan Kota Malang sejak tahun 2016 sehingga sejalan dengan konsep jaringan sosial menurut Putnam yang menyatakan bahwa masyarakat yang komunitasnya memiliki banyak jaringan sosial padat lebih konduksif bagi pembangunan ekonomi (Field, 2010:91). Dengan mempeluas ekspansi menjadi komoditas export, diharapkan kuantitas produksi emping jagung sebagai jajanan tradisional khas Kota Malang akan terus meingkat, diiringi dengan omzet yang 
meningkat sehingga akan meningkatkan kontribusi secara ekonomi bagi perkembangan Kota Malang dalam tingkat partisipasi angkatan kerja, baik laki-laki ataupun perempuan, peningkatan pendapatan daerah Kota Malang melalui pajak dan pengembangan pariwisata lokal melalui penyebarluasan jajanan tradisional Khas Kota Malang.

\section{Jaringan Sosial Home Industry dalam Sumberdaya Manusia}

Terdapat karakteristik interaksional yaitu suatu hubungan yang dilakukan oleh individu satu dengan individu yang lain di lihat dari perilaku yang dihasilkan dan proses interaksi. Karakteristik yang dilihat dari tingkah laku individu, dari proses interaksi yang terjadi antara individu dengan individu lain dibagi menjadi 5 unsur yaitu: 1. Content adalah hubungan yang ada antara individu satu dengan yang lain biasanya berdasarkan suatu tujuan tertentu. Hubungan ini dapat dipahami karena berdasarkan norma, kepercayaan dan nilai yang telah disepakati bersama antar individu. 2. Directedness adalah suatu jaringan dapat terlihat apakah suatu hubungan antara individu satu dengan yang lain hanya berupa hubungan yang beorientasi dari satu individu ke individu lain atau sebaliknya. 3. Durability adalah jaringan sosial jika individu menyadari hak dan kewajiban untuk mengindentifikasi orang lain. 4. Intensity adalah jaringan sosial dimana individu dipersiapkan untuk memiliki tanggung jawab atau memiliki kebebasan untuk mengeskpresikan haknya dalam hubungannya dengan orang lain. Hubungan tatap muka belum tentu menjamin intensitas dibandingkan dengan jarang komunikasi tetapi intensitas hubungan dapat memperlihatkan hubungan antar mereka, 5. Frequency adalah karateristik nyata dari interaksi dalam suatu jaringan yang dapat dilihat secara simpel dalam kuantitasnya yaitu kontak antar individu dalam jaringan (Wijaya, Mahendra. 2007:70)


Durability (pemilik usahapekerja, pekerja-tengkulak, pekerja-konsumen, pemilik usaha-pemerintah, pemilik usaha-pemilik modal lain)
Intensity (Kegiatan

Kemasyarakatan seperti PKK,

Pengajian dan melalui media

sosial seperti WhatsApp,

Facebook, Instagram)
Frequency (Dilakukan Setiap

hari dan dalam kurun waktu

lama karena hubungan

kekerabatan dan tetangga)

Gambar 1. karakteristik jaringan kerja di home industry Emping Jagung

Jaringan tenaga kerja dalam home industri emping jagung di Kota Malang ini masih sangat memperhatikan jaringan tetangga, dimana merupakan sebuah komunitas yang telah lama dan menetap di tempat yang sama dan saling mengenal satu sama lain (Gambar 1). Menggunakan tenaga kerja tetangga atau warga sekitar, khususnya bagi perempuan, bagi ibu rumah tangga dapat digunakan untuk memenuhi kebutuhan ekonomi dan menjalin hubungan baik antar pemilik dan tenaga kerja. Sementara bagi laki-laki tidak semua 
diprioritaskan untuk bekerja dalam industri rumahan emping jagung, karena telah banyak laki-laki sebagai kepala keluarga yang telah bekerja di luar sektor pengolahan industri emping jagung ini. Kalaupun ada, jumlahnya tidak sebanyak pada perempuan yang berprofesi sebagai ibu rumah tangga di sekitar lingkungan industri rumahan tersebut. Walaupun ada juga bantuan dari pihak keluarga yang terlibat dalam usaha tidak memungkinkan pemilik usaha untuk menerapkan sistem kekeluargaan dalam usaha, agar saling bekerjasama dan memberikan hasil produk bermutu dan berkualitas. Menggunakan tenaga kerja tetangga juga harus membuat pemilik usaha menjalin komunikasi dan keterbukaan dalam usaha, agar tidak ada kesalahpahaman dalam kerberlangungan usaha emping jagung.

Berdasarkan hasil wawancara yang dilakukan, dalam usaha industri emping jagung di Kota Malang sebagian besar merupakan usaha atau industri rumah tangga (home-industry). Usaha ini telah berjalan sejak tahun 1980an dan mempekerjakan lebih dari 15 orang dan menggunakan manajemen yang modern. Dalam usaha ini, pemiliknya berperan sebagai pimpinan perusahaan dan orang-orang yang masih memiliki hubungan dekat ditempatkan pada posisi-posisi yang membutuhkan tingkat kepercayaan yang tinggi dari pemiliknya. Misalnya posisi yang berhubungan dengan masalah uang. Proses rekrutmen yang dilakukan dalam mencari tenaga kerja dilakukan masih secara konvensional dikarenakan mengutamakan lingkungan sekitar dan mengutamakan jaringan sosial yang ada. Para pekerja dalam industri ini, baik laki-laki ataupun perempuan dipelakukan secara sama, tidak ada perbedaaan karena pekerjaan dijalankan sesuai ketrampilan berdasarkan proses magang dengan bekerja pada tetangga atau saudara yang membutuhkannya. Mereka dilatih sambil bekerja oleh pemilik usaha. Pekerja pada industri rumahan emping jagung ini biasanya masih muda dan lulusan SMA/SMK baik pekerja laki-laki ataupun pekerja perempuan.

Hubungan antara pemilik usaha dengan pekerja yang masih baru biasanya dipenuhi oleh kesabaran dan toleransi terhadap kesalahan dalam bekerja. Terhadap pekerja baru ini pemilik usaha biasanya membimbing untuk memperbaiki kesalahan-kesalahan dalam mengerjakan pekerjaan. Tidak ada tindakan memutus hubungan kerja oleh pemilik unit usaha. Pada saat pekerja sudah semakin dewasa dan terampil biasanya akan keluar dengan sendirinya mengingat gaji yang diberikan industri ini tidak semua diberikan sesuai dengan stardar Upah Minimum Kota (UMK) Malang tahun 2019. UMK Malang 2019 hanya diberikan pada karyawan tetap sementara pekerja atau buruh yang memproduksi emping jagung dibayar secara harian, mengingat sebagian dari mereka juga bekerja di tempat lain. Terkait dengan pengelolaan sumberdaya manusia, pemilik usaha emping jagung memberikan toleransi yang terbatas pada tindakan yang tidak jujur dalam bekerja. Lain halnya dengan pekerja yang sudah bersifat tetap dan dibayar sesuai UMK Malang 2019, kesalahan fatal atau kesalahan yang sering dilakukan dapat berakibat pada pemutusan hubungan kerja. Dari pola tersebut juga dapat diketahui jika komponen yang paling banyak memiliki jaringan paling luas adalah pegawai, terutama pada pegawai perempuan karena keluwesan dalam berkomunikasi, fleksibel dalam menerima pembayaran dan kooperatif dengan berbagai pihak.

Berdasarkan hasil wawancara, diketahui bahwa jaringan sosial pada home industry emping jagung di Kota Malang ini menempatkan pegawai dan pemilik dalam posisi yang 
sama atau sejajar. Jaringan sosial lainnya juga terjadi antara distributor emping jagung dengan penjual di pasar atau tengkulak. Dalam jaringan tersebut memiliki kesadaran untuk saling menjaga kepercayaan satu sama lain. Kelangsungan produksi emping jagung juga akan melibatkan hubungan antara pemilik usaha dengan supplier bahan baku, kedua belah pihak ini sudah saling percaya satu sama lain dan ada kecocokan sehingga membuat pengusaha enggan berganti-ganti supplier.

\section{Jaringan Sosial Home Industry dalam Eksistensi Usaha}

Keterkaitan hubungan jaringan sosial dengan kelangsungan usaha cenderung dalam interaksi sebagai sarana memperat tali persaudaraan satu sama lain, baik itu antar pengusaha, karyawan, buruh, tengkulak, pedagang, masyarakat, maupun aparat pemerintah Kota Malang. Selain itu manfaat yang diperoleh yaitu memperluas hubungan pertemanan dalam hal relasi atau hubungan usaha. Perlu dipahami bahwa jaringan sosial terdiri atas karakteristik morphologi dan interaksional, yang memiliki kapasitas yang berbeda-beda dimana jaringan sosial secara morphologi berdasarkan pada tingkah laku sosial individu dalam suatu jaringan sedangkan jaringan sosial secara karakteristik interaksional yang berdasarkan pada hubungan yang dilakukan oleh individu satu dengan yang lain dimana berdasarkan pada tujuan tertentu dalam suatu jaringan.

Jaringan sosial yang terjadi secara karakteritik morphologi meliputi dari jaringan sosial yang berdasarkan pada hubungan tingkah laku sosial individu yang kaitannya dengan aspek permodalan, sumber daya manusia, produksi, dan pemasaran yang dilihat dari sudut pandang karakteristik morpologi. Bahwa jaringan sosial yang terjadi antara pengusaha, karyawan, pedagang, tengkulak dan pemerintah Kota Malang menggambarkan terjadinya jaringan sosial secara morpologi meliputi anchorage dimana cenderung pada tingkah laku sosial terbentuk dalam suatu jaringan, reachability dimana cenderung pada tingkah laku yang sesuai dengan peraturan, identity cenderung pada tingkah laku yang saling kerjasama antar individu, dan range yang melihat pada komunikasi atau interaksi antar individu. Maka dapat disimpulkan bahwa jaringan sosial yang terjadi pada industri rumahan emping jagung terjadi sesuai karakteristik morphologi cenderung pada tingkah laku sosial individu yang mencerminkan adanya kerjasama supaya jaringan sosial yang terbentuk semakin luas dan dapat mengembangkan industri makanan tradisional di Kota Malang. Jaringan sosial secara morphologi ini beroerientasi pada bagaimana perilaku sosial individu dalam menjalin kerjasama dengan individu yang lain.

Jaringan sosial yang terjadi pada industri emping jagung di Kota Malang terjadi atas dasar karakteristik interaksional, yang menitikberatkan hubungan antar individu yang mencerminkan adanya interaksi dalam suatu jaringan yang saling menguntungkan supaya jaringan sosial yang terbentuk semakin luas dan mengembangkan usaha industri makanan tradisional di Kota Malang. Jaringan sosial secara interaksional ini berorientasi pada bagaimana hubungan antar individu dalam menjalin kerjasama dengan individu yang lain. Interaksi sosial yang ada dalam dalam jaringan ini menimbulkan kerjasama satu sama lain dalam segala hal, baik itu secara sosial maupun secara ekonomi, wujud dari kerjasama yang terjadi diawali dengan tindakan-tindakan dan interaksi yang dilakukan oleh para pemilik usaha emping jagung di Kota Malang. Manfaat yang dirasakan dalam jaringan sosial yang terjalin oleh pengusaha yaitu perluasaan relasi bisnis yang menimbulkan 
kerjasama, terlihat pada kelangsungan pemasaran dimana pengusaha juga mendapatkan pelanggan dari teman kegiatan, yang mulanya sebagai teman berkegiatan hubungannya menjadi pertemanan dalam hal usaha (relasi usaha). Hubungan sosial yang terjadi dalam industri rumahan ini terjadi melalui beberapa bentuk, seperti hubungan antara pengusaha dengan tenaga kerjanya., Pengusaha dengan pelangganya dan pengusaha dengan suppliernya dengan tujuan atau sebagai upaya, untuk menjaga dan mempertahankan sumber daya yang ada, yang dapat mempengaruhi kelangsungan SDM, Pemasaran, dan produksi dalam jangka panjang. Kelangsungan pemasaran cenderung mewarnai hubungan yang terjadi antara pemilik usaha dengan konsumen, pegawai dengan konsumen yang terlihat dari mekanisme pengambilan barang yang diberikan oleh pemilik usaha kepada pelanggan, baik tengkulak ataupun pedagang, yang dilakukan tempo atau tunai, dasar pemberian tempo ini diberikan pada orang yang benar-benar dipercaya dengan melihat siapa dia dan bagaimana track recordnya.

Jaringan sosial secara karateristik morphologi yang didasarkan pada tingkah laku sosial individu dan karakteritik interaksional yang dilihat melalui hubungan individu sesuai dengan tujuan sebuah jaringan dengan kelangsungan usahanya. Kedua hal tersebut merupakan penentu dalam perkembangan suatu usaha, termasuk industri emping jagung yang sedang berkembang saat ini. Melihat hal tersebut dapat diketahui mengenai suatu perkembangan suatu usaha industri melalui jaringan sosial dan kelangsungan usaha di masa depan. Dalam aspek sosiologi ekonomi, jaringan sosial yang terjadi secara morphologi dan interaksional sangat berkaitan dengan kelangsungan usaha di masa depan. Dalam konteks ini, jaringan sosial akan menentukan kelangsungan usaha, sementara kelangsungan usaha terjadi melalui suatu jaringan sosial dalam sebuah usaha sehingga mampu meningkatkan serta mewujudkan eksistensi sebuah usaha di masa depan.

\section{KESIMPULAN}

Hubungan sosial yang tercipta dalam masyarakat memperluas jaringan-jaringan sosial dari pengusaha, pegawai, buruh, supplier, tengkulak, dan Pemerintah Kota Malang. Relasi ekonomi yang didasarkan pada interkasi sosial berbasis gender ini merupakan wujud kerjasama dalam kegiatan usaha, baik berupa pemasaran, produksi, modal, tenaga, kerja dan lainnya. Jaringan sosial sangat terkait erat dengan keberlangsungan usaha, karena dengan memanfaatkan jaringan sosial dapat menjamin keberlangsungan usaha dari pengusaha sendiri. Melalui jaringan sosial, tercipta interaksi antar individu yang menjadi dasar kerjasama saling menguntungkan atau mutualis serta hubungan sosial yang berdasarkan pada norma dan nilai yang berlaku dalam kesepakatan bersama..

\section{DAFTAR PUSTAKA}

Anggaunitakiranantika, A., 2018. Konstruksi Sosial Pekerja Perempuan dan Anak pada Industri Perikanan. Sawwa: Jurnal Studi Gender, 13(1)

Arifin, H., 2004. Cara Memahami Kerentanan Perempuan Pengusaha Kecil. Bandung: AKATIGA.

Damsar, 2002. Sosiologi Ekonomi. Jakarta : PT. RajaGrafindo Persada.

Djoharwinarlien, Sri. 2012. Dilema Kesetaraan Gender. Yogyakarta: PolGov Fisipol UGM 
Faisal, Sanafiah. 2003. Format-Format Penelitian Sosial. Jakarta: PT Raja Grafindo Persada

Moleong, L. J. 2004. Metodologi Penelitian Kualitatif. Bandung: Remaja Rosdakarya

Field, John, 2010. Modal Sosial. Yogyakarta: Kreasi Wacana.

Hefner, R. W. 2018. Market cultures: society and morality in the new Asian capitalisms. United Kingdom: Routledge.

Hidayati, N., Kiranantika, A. and Pujirahayu, S.E., 2019. January. The Identification of Female Workers in Handcraft Embroidery Industry Based on The Factors Shaping Their Work Behavior. In 2nd International Conference on Vocational Education and Training (ICOVET 2018). Atlantis Press.

Jamasy, Owin, 2004. Keadilan, Pemberdayaan \& Penanggulangan Kemiskinan. Jakarta: Belantika.

Kumalasari, L. D. 2017. Problem UKM Dalam Pengembangan Usaha: Studi Pada UKM di Desa Mulyoarjo Lawang Malang. JURNAL SOSIAL POLITIK, 3(1), 58-77.

Mudiarta, K. G. 2017. Jaringan Sosial (Networks) dalam Pengembangan Sistem dan Usaha Agribisnis: Perspektif Teori dan Dinamika Studi Kapital Sosial. In Forum Penelitian Agro Ekonomi (Vol. 27, No. 1, pp. 1-12).

Powell, Walter. 1990. Neither Market Nor Hierarchy: Network Forms of Organization. Research in Organizational Behaviour. 12. 295-336.

Purnomo, A. (2015). Study of Gender in Adaptation Strategies Post Kelud Volcano Eruption 2014. 1st UPI International Conference on Sociology Education (UPI ICSE 2015) (pp. 416-419). Bandung: Atlantis Press.

Ritzer, George \& Douglas J. Goodman. 2004. Teori Sosiologi Modern. Jakarta: Prenada Media.

Ritzer, George. 2007. Sosiologi Ilmu Pengetahuan Berparadigma Ganda. Jakarta : PT. Raja Grafindo Persada.

Ruky, S.Ahmad. 2003. Sumber Daya Manusia Berkualitas" Mengubah Visi Menjadi Realitas”. Jakarta : Gramedia Pustaka Utama.

Soekarwo, 2018. Berkaca Dari Kegagalan Liberalisasi Ekonomi. Jakarta: PT Elex Media Komputindo

Syahra, R. 2003. Modal sosial: Konsep dan aplikasi. Jurnal Masyarakat dan Budaya, 5(1), $1-22$.

Visvanathan, Nalini (et.al). 2005. The Women, Gender and Development Reader. USA: Zed Books

Wijaya, Mahendra. 2007. Sosiologi Ekonomi. Surakarta: Lindu Pustaka

https://malangkota.bps.go.id/publication/2017/08/12/af218a8b74d037b3f9d87c85/kotamalang-dalam-angka-2017.html, diakses pada 28 maret 2019. 13:47 WIB

https://malangkota.bps.go.id/publication/2018/08/16/c99aac182fb1c32d2be35e49/kotamalang-dalam-angka-2018.html, diakses pada 28 maret 2019. 14:10 WIB. 